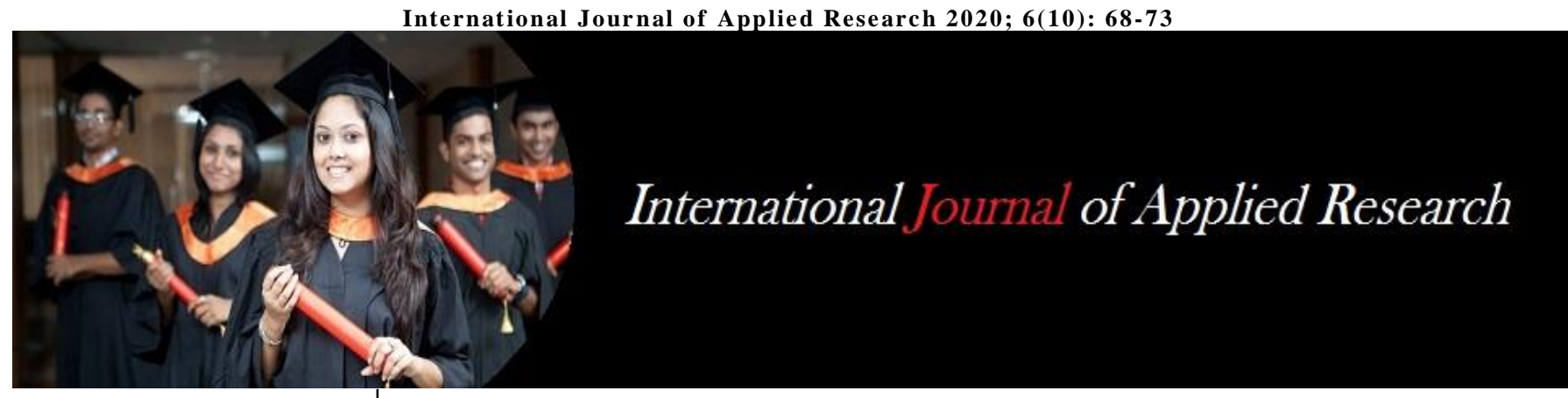

ISSN Print: 2394-7500

ISSN Online: 2394-5869

Impact Factor: 5.2

IJAR 2020; 6(10): 68-73

www.allresearchjournal.com

Received: 06-08-2020

Accepted: 09-09-2020

\section{Hanna Wijaya}

Doctor Internship at Kalideres

Hospital, Jakarta for the

Period, Indonesia

Yohanes Firmansyah

Doctor Internship at Kalideres

Hospital, Jakarta for the

Period, Indonesia

Yana Sylvana

Doctor Internship at Kalideres

Hospital, Jakarta for the

Period, Indonesia

Ernawati

Department of Public Health,

Tarumanagara University,

Jakarta, Indonesia
Corresponding Author:

Yohanes Firmansyah

Doctor Internship at Kalideres

Hospital, Jakarta for the

Period, Indonesia

\section{Improvement of random blood glucose on diabetes mellitus type ii patients with medication box interventions and individual education methods}

\author{
Hanna Wijaya, Yohanes Firmansyah, Yana Sylvana and Ernawati
}

DOI: $\underline{\text { https://doi.org/10.22271/allresearch.2020.v6.i10b.7225 }}$

\begin{abstract}
Introduction: Diabetes caused 1.5 million deaths in 2012. High blood glucose resulted in an additional 2.2 million deaths, by increasing the risk of cardiovascular and other diseases. Non-compliance with treatment diabetes mellitus patients can potentially increase morbidity, mortality and treatment costs. The aim of this study is to improve medication adherence and controlled random blood glucose in the hope reduce mortality and morbidiry of diabetes.

Method: Quasi experimental in Posbindu RW 003 and 006 Kedaung Kaliangke with samples of diabetes mellitus type 2 , the sampling method was total sampling. The independent variable was an intervention that was carried out in the form of giving a medicine box, calendar, individual education and taking medication. The dependent variable was the change in RBG.

Result: 20 respondents who met the inclusion criteria. The mean RBG before intervention was 253 $(201$ - 591) $\mathrm{mg} / \mathrm{dL}$ and the mean RBG after intervention was 182.5 (130 - 220) $\mathrm{mg} / \mathrm{dL}$. Wilcoxon Test showed that there were significant differences in RBG levels between before and after the intervention (p-value: 0.001).

Conclusion: Knowledge enhancement through individual education has proven to be effective in increasing adherence to type 2 diabetes mellitus treatment and controlled RBG.
\end{abstract}

Keywords: Diabetes; random blood glucose; medication box interventions; individual education methods; public health

\section{Introduction}

Diabetes is a serious chronic disease that occurs because the pancreas does not produce enough insulin (a hormone that regulates blood sugar or glucose), or when the body cannot effectively use the insulin it produces. Diabetes is an important public health problem, being one of the four priority non-communicable diseases that are being targeted by world leaders. The number of cases and the prevalence of diabetes have continued to increase over the past few decades ${ }^{[1,2]}$.

Criteria for diagnosis of diabetes mellitus (DM) according to American Diabetes Association (ADA) 2011 and Perkumpulan Endokrinologi Indonesia (PERKENI) 2011 guidelines: [1] Fasting plasma glucose $\geq 126 \mathrm{mg}$ / dl with concomitant classic symptoms; ${ }^{[2]}$ Glucose 2 hours after loading $\geq 200 \mathrm{mg} / \mathrm{dl}$; ${ }^{[3]}$ Random plasma glucose when $\geq 200 \mathrm{mg} / \mathrm{dl}$ if there are classic DM complaints such as urinating (polyuria), drinking a lot (polydipsia), eating a lot (polyphagia), and weight loss that can't be explained ${ }^{[3-5]}$. Whereas the diagnosis criteria for DM in Indonesia according to the PERKENI 2015 consensus are: ${ }^{[1]}$ Fasting plasma glucose examination $\geq 126 \mathrm{mg} / \mathrm{dl}$. Fasting is a condition of no calorie intake of at least 8 hours, OR [2] Examination of plasma glucose $\geq 200 \mathrm{mg} / \mathrm{dl} 2$ hours after Oral Glucose Tolerance Test (OGTT) with a glucose load of 75 grams, OR ${ }^{[3]}$ Examination of plasma glucose during $\geq 200$ $\mathrm{mg} / \mathrm{dl}$ with classic complaints (polyuria, polydipsia, polyphagia and unexplained weight loss), OR ${ }^{[4]}$ HbA1c examination $16.5 \%$ using a standardized method by the National Glycohaemoglobin Standarization Program (NGSP) ${ }^{[6]}$.

WHO data shows that the incidence of non-communicable diseases in 2004 which reached $48.30 \%$ was slightly greater than the incidence of communicable diseases, which amounted to $47.50 \%$. In fact, non-communicable diseases are the number one cause of death in the world $(63.50 \%)^{[7]}$. 
Diabetes caused 1.5 million deaths in 2012. Blood glucose higher than the maximum limit resulted in an additional 2.2 million deaths, by increasing the risk of cardiovascular and other diseases. Forty-three percent (43\%) of these 3.7 million deaths occurred before the age of 70 years. The percentage of deaths due to diabetes that occurs before age 70 is higher in low and middle income countries than in high income countries ${ }^{[1,2]}$.

WHO estimates that 422 million adults over the age of 18 lived with diabetes in 2014. The largest number of people with diabetes is estimated to come from Southeast Asia and the Western Pacific, accounting for about half the cases of diabetes in the world. Around the world, the number of diabetics has increased substantially between 1980 and 2014, increasing from 108 million to 422 million or around four times ${ }^{[1,2]}$.

In addition to cardiovascular disease, DM is also one of the main causes of kidney disease and blindness at the age of under 65 years, and also amputation ${ }^{[8]}$. Diabetes also causes amputations (which are not caused by trauma), disability, to death. Another impact of diabetes is reducing life expectancy by 5-10 years. Life expectancy for people with type 2 diabetes who suffer from serious mental illnesses, such as schizophrenia, is even $20 \%$ lower compared to the general population $[7,9,10]$.

Indonesia is ranked 7th with the highest number of people with diabetes mellitus in the world. The International Diabetes Federation (IDF) states that in 2016 Indonesia had around 9.1 million people with DM. It is estimated that this number could increase to 12.4 million people in 2025 and reach 14.1 million in $2035^{\text {[11] }}$. Infodatin in 2018 released data that the prevalence of people with Type 2 Diabetes Mellitus in Indonesia is $2.0 \%$. This figure experienced a significant increase from 2013 which was only $1.5 \%$. One of the regions with the highest number of diabetics in Indonesia is DKI Jakarta with a prevalence of DM sufferers of $3.4 \%$, which ranks number 1 out of 34 provinces and includes 1 of 13 provinces with regional prevalence above the national prevalence. The prevalence of DM in DKI Jakarta has experienced a significant increase from 2013 which was only $2.5 \%$. $^{[12-14]}$

The Indonesian Nephrology Association (Pernefri) in 2006 released data on patients with chronic kidney failure in Indonesia of $12.5 \%$. The accompanying diseases of stage 5 chronic kidney patients according to the Indonesian Renal Registry in 2018 are $51 \%$ hypertension and $21 \%$ diabetes mellitus type $2 .{ }^{[15]}$. Diabetes and its complications bring huge economic losses for diabetics and their families, the health system and the national economy through direct medical costs, job loss and income. Included in the main cost components are hospital and outpatient care, another factor that requires large costs is the increase in costs for analog insulin 1 which is increasingly being prescribed despite little evidence that this type of insulin has a significant effect compared to cheaper human insulin. It is therefore important to control blood glucose levels of diabetes mellitus type 2 patients before complications occur later in life. Controlling the random blood glucose content of DM patients through comprehensive treatment, namely management in a pharmacological and non-pharmacological manner ${ }^{[16]}$.

A self-report scale to assess adherence to the use of antihypertensive drugs has been developed by Morisky. A study to test psychometrics and predict the validity of the self report medication adherence structure was tested on 1367 hypertensive patients. Self report adherence to drug use was measured by the new 8 item self report Morisky Medication Adherence Scale (MMAS) ${ }^{[17]}$.

Seeing the importance of adherence to taking medication in people with diabetes mellitus to prevent complications later in life. This research was conducted to improve medication adherence in patients with diabetes mellitus and provide education about the importance of taking medication regularly to random blood glucose (RBG) in the hope of reducing the morbidity and mortality rates of diabetes mellitus

\section{Method and material}

This research is a quasi-experimental study carried out in Posbindu RW 003 and 006 Kedaung Kaliangke Sub-District Jakarta in January 2020 to February 2020. The sample of this study was uncontrolled type 2 diabetes mellitus sufferers or Random Blood Glucose (RBG) when measurements were above $200 \mathrm{mg} / \mathrm{dL}$. The estimated sample size in this study is 30 respondents with a total sampling method in the form of sampling. This experimental study doesn't include control grup. The inclusion criteria in this study were people with diabetes mellitus type 2 not controlled. Exclusion criteria in this study were patients with other non-communicable diseases besides diabetes mellitus type 2, diabetes mellitus type 1, gestational diabetes, and diabetes mellitus type 2 patients who had complications or treatment using insulin.

This research was carried out by measuring medication adherence and blood glucose before and after the intervention. The intervention was in the form of individual education for patients with type 2 diabetes mellitus, administration of taking medication boxes, as well as a calendar of reminders of control to the Puskesmas when the usual medication was consumed. The intervention lasted for 1 month and was monitored by the families of sufferers and local cadres. The independent variable in this study was an intervention that was carried out in the form of giving a medicine box, calendar, individual education and taking medication. The dependent variable in this study was the change in blood glucose at a time. Paired numerical categorical statistical analysis using the Pair T-Test statistical test with an alternative test in the form of Wilcoxon, and paired categorical categorization using the McNemar Test to assess the significance between the 2 groups. This study has obtained permission from the Puskesmas Kelurahan Kedaung Kaliangke and the Puskesmas Kecamatan Cengkareng.

\section{Results}

Hasil dan pembahasan hasil dan pembahasan hasil dan pembahasan. The data collection process was carried out in January 2020 - February 2020 by conducting a survey through a questionnaire that we gave to patients with diabetes mellitus type 2 at Puskesmas Kelurahan Kedaung Kaliangke. Screening was carried out in January - February 2020 in posbindu RW 003 and 006, followed by 20 respondents with $4(20 \%)$ male respondents and $16(80 \%)$ women. The average age of 57 years with an age range is $22-78$ years. Generally respondent education is Elementary School with 11 respondents (55\%). Respondents generally work as housewives by 13 respondents (65\%). The characteristics of respondents are in table 1. 
Table 1: Demographic Characteristics of Respondents in Posbindu RW 003 and 006, Kedaung Kaliangke Sub-District, Cengkareng District, Jakarta

\begin{tabular}{|c|c|c|c|}
\hline Parametric & N (\%) & Mean (SD) & Med (Min - Max) \\
\hline Gender & $4(20 \%)$ & & \\
Male & $16(80 \%)$ & & \\
Female & & $52,32(9,52)$ & $57(22-78)$ \\
\hline Age & $2(10 \%)$ & & \\
\hline Educational & & \\
No School & $11(55 \%)$ & & \\
Elementary School & $5(25 \%)$ & & \\
Middle School & $2(10 \%)$ & & \\
High School & - & & \\
University & & & \\
Work & $13(65 \%)$ & & \\
Housewifes & $2(10 \%)$ & & \\
General employees & $5(25 \%)$ & & \\
None & & & \\
\hline
\end{tabular}

Profile history of diabetes mellitus type 2 patients is described in table 2. Generally respondents suffer from type 2 diabetes mellitus for 1-5 years ie 10 respondents $(50 \%)$. History of diabetes mellitus control to the Puskesmas or Posbindu generally controlled by 17 respondents $(85 \%)$. Generally patients $16(80 \%)$ do not have a history of type 2 diabetes mellitus in the family. The characteristics of the respondents are listed in table 2

Table 2: Historical Characteristics of Diabetes Mellitus Type 2 Patients in Posbindu RW 003 dan 006, Kedaung Kaliangke SubDistrict, Cengkareng District, Jakarta

\begin{tabular}{|c|c|}
\hline Parametric & N (\%) \\
\hline Time of Diabetes Mellitus type 2 & $3(15 \%)$ \\
Less than 1 year & $10(50 \%)$ \\
$1-5$ years & $3(15 \%)$ \\
$5-10$ years & $4(20 \%)$ \\
Above 10 years & $17(85 \%)$ \\
\hline Control Diabetes Mellitus type 2 & $3(15 \%)$ \\
to the Puskesmas or Posbindu & \\
Yes &
\end{tabular}

\begin{tabular}{|c|c|}
\hline No & \\
\hline Family History & $4(20 \%)$ \\
Yes & $16(80 \%)$ \\
No & \\
\hline
\end{tabular}

Compliance Profile Taking Medication Respondents before the intervention can be said to be quite bad with the number of respondents who forgot to take medication $16(80 \%)$, did not take medication for various reasons $15(75 \%)$, reduced or stopped the drug without the knowledge of doctors 16 $(80 \%)$, forgot to bring medication $16(80 \%)$, did not take medication yesterday $13(65 \%)$, stopped taking medication when there were improvement in symptoms 14 (70\%), felt disturbed to ask for medication 14 (70\%), and difficulty remembering medication taken 18 (90\%). Providing individual and in-depth education is carried out to all individuals and taking a medication compliance profile measurement one month later and the results obtained are improved in all aspects of the question being assessed ( $p$ value $<0.05$ )

Table 3: Compliance Profiles of Respondent Medication Taking Before and After Intervention

\begin{tabular}{|c|c|c|c|c|c|c|}
\hline \multirow[t]{2}{*}{ No } & \multirow[t]{2}{*}{ Items } & \multicolumn{2}{|c|}{$\begin{array}{c}\text { Pre } \\
\text { Intervention }\end{array}$} & \multicolumn{2}{|c|}{$\begin{array}{c}\text { Post } \\
\text { Intervention }\end{array}$} & \multirow[t]{2}{*}{$\boldsymbol{P}$} \\
\hline & & Yes & No & Yes & No & \\
\hline 1 & Do you sometimes forget to take your medications? & $\begin{array}{c}16 \\
(80 \%)\end{array}$ & $\begin{array}{c}4 \\
(20 \%)\end{array}$ & $\begin{array}{c}6 \\
(30 \%)\end{array}$ & $\begin{array}{c}14 \\
(70 \%)\end{array}$ & $<0.05$ \\
\hline 2 & $\begin{array}{l}\text { People sometimes miss taking their medications for reasons other than forgetting, } \\
\text { Thinking over the past two weeks, were there any days when you did not take } \\
\text { your medicine? }\end{array}$ & $\begin{array}{c}15 \\
(75 \%)\end{array}$ & $\begin{array}{c}5 \\
(25 \%)\end{array}$ & $1(5 \%)$ & $\begin{array}{c}19 \\
(95 \%)\end{array}$ & $<0.05$ \\
\hline 3 & $\begin{array}{l}\text { Have you ever cut back or stopped taking your medication without telling your } \\
\text { doctor, because you felt worse when you took it? }\end{array}$ & $\begin{array}{c}16 \\
(80 \%)\end{array}$ & $\begin{array}{c}4 \\
(20 \%)\end{array}$ & - & $\begin{array}{c}20 \\
(100 \%)\end{array}$ & $<0.05$ \\
\hline 4 & $\begin{array}{l}\text { When you travel or leave home, do you sometimes forget to bring along your } \\
\text { medications? }\end{array}$ & $\begin{array}{c}16 \\
(80 \%) \\
\end{array}$ & $\begin{array}{c}4 \\
(20 \%) \\
\end{array}$ & - & $\begin{array}{c}20 \\
(100 \%)\end{array}$ & $<0.05$ \\
\hline 5 & Did you take your medications yesterday? & $\begin{array}{c}7 \\
(35 \%)\end{array}$ & $\begin{array}{c}13 \\
(65 \%)\end{array}$ & $\begin{array}{c}20 \\
(100 \%)\end{array}$ & - & $<0.05$ \\
\hline 6 & $\begin{array}{l}\text { When you feel like your condition is under control, do you sometimes stop } \\
\text { taking your medicine? }\end{array}$ & $\begin{array}{c}14 \\
(70 \%) \\
\end{array}$ & $\begin{array}{c}6 \\
(30 \%) \\
\end{array}$ & - & $\begin{array}{c}20 \\
(100 \%) \\
\end{array}$ & $<0.05$ \\
\hline 7 & $\begin{array}{l}\text { Taking medication everydays is a real inconvenience for some people. Do you } \\
\text { ever feel hassled about sticking to your treatment plan? }\end{array}$ & $\begin{array}{c}14 \\
(70 \%)\end{array}$ & $\begin{array}{c}6 \\
(30 \%)\end{array}$ & - & $\begin{array}{c}20 \\
(100 \%)\end{array}$ & $<0.05$ \\
\hline 8 & How often do you have difficulty remembering to take all your medications? & $\begin{array}{c}18 \\
(90 \%)\end{array}$ & $\begin{array}{c}2 \\
(10 \%)\end{array}$ & $\begin{array}{c}6 \\
(30 \%)\end{array}$ & $\begin{array}{c}14 \\
(70 \%)\end{array}$ & $<0.05$ \\
\hline
\end{tabular}

Measurement of random blood glucose is done before and after the intervention in the form of administering pillboxes, calendars, individual education and taking medication. The mean random blood glucose before intervention was 253 (201 - 591) $\mathrm{mg} / \mathrm{dL}$ and the mean random blood glucose after intervention was 182.5 (130 - 220) mg / dL. Wilcoxon statistical test results showed there were significant changes in random blood glucose between before and after the intervention (p-value: 0.001) 
Table 4: Mean Changes in Random Blood Glucose Respondent Pre-Post Interventions

\begin{tabular}{|c|c|c|c|c|c|c|}
\hline Parametric & Normality & Mean (SD) & $\begin{array}{c}\text { Med } \\
\text { Min-Max) }\end{array}$ & Mean Difference & Confidence Interval & p-value \\
\hline \multicolumn{7}{|c|}{ Random Blood Glucose } \\
\hline Pre-Intervention & 0,001 & $280,15(96,01)$ & $253(201-591)$ & $103,5(97,64)$ & $57,80-149,20$ & $<0,001$ \\
\hline Post Intervensi & 0,060 & $176,65(22,73)$ & $182,5(130-220)$ & 100 &
\end{tabular}

At the beginning of the study 20 respondents were obtained with blood glucose when uncontrolled or above $200 \mathrm{mg} /$ $\mathrm{dL}$. Interventions were given to all respondents in the form of interventions giving medicine boxes, calendars, individual education and supervision of taking drugs. One month of intervention took place and the results showed that $18(90 \%)$ of respondents experienced blood glucose regulation when controlled or below $200 \mathrm{mg} / \mathrm{dL}$.

Table 5: Changes in Blood Glucose Status Respondent Pre-Post Interventions

\begin{tabular}{|c|c|c|c|c|}
\hline \multicolumn{2}{|c|}{ Parametric } & \multicolumn{2}{c|}{ Diabetic State Post Intervension } & \multirow{2}{*}{ p-value } \\
\cline { 3 - 4 } & Uncontrolled & Controlled & \multirow{2}{*}{0,001} \\
\hline \multirow{2}{*}{ Diabetic State Pre Intervension } & Uncontrolled & $2(10 \%)$ & $18(90 \%)$ & - \\
\cline { 2 - 4 }
\end{tabular}

\section{Discussion}

Respondents who experience abnormal blood glucose based on changes in pancreatic hormones as regulators of the most important substances in the body's metabolism cause an increase in stress hormones, ephinephrine and cortisol which increase glucose levels and fatty acids in the blood. High glucose levels stimulate the formation of glycogen from glucose, synthesis of fatty acids and cholesterol from glucose. High blood glucose levels can accelerate the formation of triglycerides in the liver. Triglyceride is one part of the fat composition in the body, where if triglyceride levels are within normal limits it has a function as a source of energy in the body while triglyceride levels in the abnormal range increase blood glucose levels as a cause of type II diabetes mellitus ${ }^{[18]}$

How to reduce blood glucose levels in Diabetes Mellitus Type II patients in addition to obediently taking medication on time and according to the recommended dosage of health workers also need to control weight through exercise and healthy eating. According to Bustan (2007) explains the form of weight control by doing 30 minutes of physical activity every day or exercising 5 days per week such as morning jogging, and doing healthy eating patterns by reducing glucose consumption and fatty foods ${ }^{[19,20]}$.

Knowledge is interpreted as the level of patient behavior in implementing diabetes mellitus type 2 treatment and the behavior suggested by doctors and others, and controlled diabetes is influenced by the level of diabetes patient's knowledge of his disease ${ }^{[21]}$. Patient's knowledge about DM is a tool that can help patients carry out DM management during his lifetime. Patient behavior based on positive knowledge and attitude will last. Knowledge given to patients with DM, will make patients understand about the disease and understand how to change behavior in dealing with the disease ${ }^{[22,23]}$.

Diabetes mellitus is a disease that has a lifetime, the role of general practitioners as the spearhead in primary health care is very important. Management of this disease requires the participation of doctors, nurses, nutritionists, and other health workers. Patients and their families are entitled to get knowledge and education about the course of the disease, prevention, complications, and management of $\mathrm{DM}^{[22,23]}$.

Adherence in patients with type 2 diabetes is generally defined as the level of behavior of someone who is getting treatment for diet, taking medication and carrying out a lifestyle in accordance with the recommendations of health care providers ${ }^{[24]}$ Patients who do not understand DM, often do not comply with DM treatment ${ }^{[25]}$ The success of DM treatment is highly dependent on the patient's compliance with taking medication. Several previous studies on the relationship between knowledge and adherence to taking medication have shown different results ${ }^{[26-28]}$.

Types of non-compliance with drug therapy include failure to redeem medication, missed doses, errors in drug administration time, and premature drug withdrawal. Noncompliance will result in the use of a drug that is less so that it makes the therapeutic benefits reduced. Non-compliance can also result in the use of excessive doses of the drug. If the dose is overused or if the drug is consumed more frequently than the recommended recommendation, it can create greater side effects. Problems like this often arise in patients who forget to take one dose of the drug and double the next dose ${ }^{\text {[29] }}$

The level of knowledge is one of the factors in influencing the level of adherence to take medication, so providing indepth information about diabetes mellitus is very important to do so that the level of adherence to take medication increases and the risk of disease severity and complications decreases, and blood glucose can be controlled ${ }^{[26]}$

Knowledge is a very important domain for action to be formed, the necessary elements include understanding what is done, beliefs about the benefits and truth of what is done and the means needed to do it. Action is an internal response after thought and knowledge. This behavior or act of obedience is influenced by heredity, environment, and knowledge ${ }^{[30]}$.

The success of therapy in patients with diabetes mellitus shows an increase in the quality of life of patients and avoid complications. The success of therapy is influenced by adherence, motivation, and family support. The success of diabetes mellitus therapy can be improved by regulating the diet, monitoring blood glucose levels, maintaining foot hygiene and the portion of exercise ${ }^{[31]}$. Improvement in the quality of life of patients with DM is influenced by the success of treatment. Less optimal treatment results are generally caused by patient non-compliance, inaccurate prescribing, and inaccurate monitoring ${ }^{[32]}$. Patient noncompliance increases the risk of complications and worsens the illness ${ }^{[33]}$.

Study form Puspita Nur Hapsari (2014) was conducted in 92 patients with type 2 diabetes mellitus in outpatient RS X the control and getting oral antidiabetic in March 2014. The 
conclusion of this study is a correlation between adherence scores with decreased fasting blood glucose levels very low which that medication adherence affects therapeutic outcome of $0,4 \%{ }^{[31]}$.

Research conducted at Mandau Health Center in Bengkalis Regency shows that the knowledge of DM Type 2 patients is generally at a moderate level and the level of medication adherence is relatively high. There is a relationship between knowledge of patients with diabetes Type 2 with adherence to take medication with a weak correlation level ${ }^{[26]}$.

Research from Adelaide B, et al. (2019) explained that less than half $(47.3 \%)$ of diabetes mellitus type II patients had moderate medication adherence and more than half $(60.0 \%)$ of diabetes mellitus type II patients experienced abnormal blood glucose levels. while the Spearman rank correlation results obtained $\mathrm{p}$ value $=(0.004)<(0.050)$ so that it can be concluded that there is a significant relationship between the level of adherence to take medication with blood glucose levels in patients with diabetes mellitus type II at Dinoyo Public Health Center, Malang ${ }^{[34]}$.

The research form Oryza DN (2018) explains patients with unregulated blood glucose showed $46.2 \%$ people were obedient and $53.8 \%$ were not obedient in consuming antidiabetic drugs. Patients with regulated blood glucose showed $92.3 \%$ people were obedient and $7.7 \%$ people were not obedient in consuming anti-diabetic drugs. Chi square test showed that there was a relationship between antidiabetic drugs consumption adherence and blood glucose level regulstion for diabetes mellitus patients with $\mathrm{p}=0.015$ $(p<0.05)$ and an OR value of 14 with a 95\% CI (1.385141.485), which means that unobedient have 14 times risker suffered terrible blood glucose regulation than obedient patients ${ }^{[35]}$.

Research conducted by Natalia and Dwipayant (2013), proves that there is a relationship between the level of adherence to take medication with blood glucose levels in DM Type II patients with a p value of 0.003 . Prevention of increased blood glucose levels in patients with diabetes mellitus type II that is controlling weight by exercising and eating healthy. This form of control is done by losing a little weight (5-7\% of total body weight) accompanied by 30 minutes of physical activity or exercise 5 days per week, adjusted for eating healthy enough ${ }^{[36]}$.

\section{Conclusion}

Knowledge enhancement through individual education has proven to be effective in increasing adherence to type 2 diabetes mellitus treatment. Regular treatment will make changes in random blood glucose as meaningful being more controlled ( $p$-value <0.05).

\section{Conflict of interest}

All authors and parties declare that there is no Conflict of Interest

\section{Acknowledgments}

Acknowledgments We extend our heartfelt thanks to all parties who participated in the completion of this study. Thanks to Dr. Wisnu Eko Prasetyo as the Head of the Cengkareng District Health Center who has given research permission, Ms. Sunarti as the holder of a noncommunicable disease program Puskesmas Kedaung Kaliangke, and all Kedaung Kaliangke Health Center employees.

\section{Ethical clearance}

The research feasibility process and research ethics have been approved by the Cengkareng District Health Center

\section{Funding}

Self - Funding

\section{References}

1. World Health Organization. Global Report on Diabetes. Isbn 2016.

2. World Health Organization. Global Report on Diabetes Executive Summary. Www.Who.Int/Diabetes/Global Report 2017.

3. American Diabetes Association. Standard medical care in diabetes 2018. J Clin Appl Res Educ 2018;

4. American Diabetes Association. Summary of revisions to the 2011 clinical practice recommendations. Diabetes Care 2011.

5. Perkeni. Konsensus Pengolahan Dan Pencegahan Diabetes Melitus Tipe 2 Di Indonesia. Perkumpulan Endokrin Indonesia 2011.

6. Soelistijo SA, Novida H, Rudijanto A, Soewondo P, Suastika K, Manaf A, et al. Konsensus Pengendalian dan Pencegahan Diabetes Melitus Tipe 2 di Indonesia 2015. Perkeni 2015.

7. Garnita D. Faktor Resiko Diabetes Melitus di Indonesia (Analisis Data Sakerti 2007). Skripsi Fak Kesahatan Masy Progr Stud Kesehat Masy Univ Indones 2012.

8. Marshall SM, Flyvbjerg A. Diabetic Nephropathy. In: Textbook of Diabetes: Fourth Edition 2010.

9. Garnita. Faktor-faktor Penyebab Diabetes Melitus. J Chem Inf Model 2016.

10. Goldberg RB. The new clinical trials with thiazolidinediones - DREAM, ADOPT, and Chicago: Promises fulfilled? Current Opinion in Lipidology 2007.

11. International Diabetes Federation [IDF]. Eighth edition 2017. IDF Diabetes Atlas, 8th edition 2017.

12. Riset Kesehatan Dasar (Riskesdas). Laporan Nasional Riskesdas 2018. Badan Penelitian dan Pengembangan Kesehatan Riset 2019.

13. Riskesdas. Hasil Utama Riskesdas Tentang Prevalensi Diabetes Mellitus di Indonesia 2018. Has Utama Riskesdas Tentang Prevalensi Diabetes Melitus di Indones 2018.

14. Riskesdas. Hasil Utama Riskesdas Penyakit Tidak Menular 2018. Has Utama Riskesdas Penyakit Tidak Menular 2018.

15. Ppernefri. Program Indonesian Renal Registry. Report of Indonesian Renal Registry 2016. Perkumpulan Nefrol Indones 2016.

16. Kemenkes RI. Prevalensi Penderita Diabetes. Infodatin 2014.

17. Morisky DE, Ang A, Krousel-Wood M, Ward HJ. Predictive validity of a medication adherence measure in an outpatient setting. J Clin Hypertens 2008.

18. Sherwood L. Pembuluh Darah dan Tekanan Darah. In: Fisiologi Manusia dari Sel ke Sistem 2015.

19. Soegondo S, Purnamasari D. Sindrom Metabolik. Dalam Sudoyo, dkk Buku Ajar Ilmu Penyakit Dalam 2010.

20. Soegondo S. Farmakoterapi pada Pengendalian Glikemia Diabetes Mellitus Tipe 2. Buku Ajar Ilmu Penyakit Dalam Ed VI Jilid 2014, 2 
21. Notoatmodjo S. Promosi Kesehatan dan Perilaku Kesehatan. Journal of Chemical Information and Modeling 2012.

22. Kementerian Kesehatan RI. Rencana Strategis Kementerian Kesehatan Republik Indonesia Tahun 2015-2019. Pus Komun Publik 2015.

23. Kemenkes. Diabetes melitus penyebab kematian nomor 6 di dunia; Kemenkes tawarkan solusi cerdik melalui Posbin. Kemenkes RI 2013.

24. Ilmah F, Rochmah TN. Kepatuhan Pasien Rawat Inap Diet Diabetes Mellitus Berdasarkan Teori Kepatuhan Niven. J Adm Kesehat Indones 2015.

25. Putri LK, Karimi J, Nugraha DP. Profil Pengendalian Diabetes Melitus Tipe 2 Di Poliklinik Penyakit Dalam RSUD Arifin Achmad Pekanbaru. J Ilmu Kedokt 2017.

26. Nazriati E, Pratiwi D, Restuastuti T. Pengetahuan pasien diabetes melitus tipe 2 dan hubungannya dengan kepatuhan minum obat di Puskesmas Mandau Kabupaten Bengkalis. Maj Kedokt Andalas 2018.

27. Waghachavare V, Gore A, Chavan V, Dhobale R, Dhumale G, Chavan G. Knowledge about diabetes and relationship between compliance to the management among the diabetic patients from Rural Area of Sangli District, Maharashtra, India. J Fam Med Prim Care 2015.

28. Sumedh Mandpe A. Correlation of Disease Knowledge with Adherence to Drug Therapy, Blood Sugar Levels and Complications Associated with Disease among Type 2 Diabetic Patients. J Diabetes Metab 2014.

29. Pramestutie HR, Silviana N. The Knowledge Level of Hypertension Patients for Drug Therapy in the Primary Health Care of Malang. Indones J Clin Pharm 2016.

30. Manan S. Hubungan Tingkat Pengetahuan Dengan Kepatuhan Dalam Upaya Mengontrol Gula Darah Di Poliklinik RS. Immanuel Bandung. J Chem Inf Model 2014.

31. Hapsari PN. Hubungan Antara Kepatuhan Penggunaan Obat dan Keberhasilan Terapi Pada Pasien Diabetes Mellitu Instalasi Raawat Jalan di RS X Surakarta. Unpublished 2014.

32. Hepler CD, Strand LM. Opportunities and responsibilities in pharmaceutical care. Am J Hosp Pharm 1990.

33. Pratita ND. Hubungan Dukungan Pasangan dan Health Locus of Control Dengan Kepatuhan Dalam Menjalani Proses Pengobatan Pada Penderita Diabetes Mellitus Tipe-2. J Ilm Mhs Univ Surabaya 2012.

34. Bulu A, Wahyuni TD, Sutriningsih A. Hubungan Antara Tingkat Kepatuhan Minum Obat Dengan Kadar Gula Darah Pada Pasien Diabetes Melitus Tipe II. Nurs News (Meriden) 2019.

35. Nanda OD, Wiryanto B, Triyono EA. Hubungan Kepatuhan Minum Obat Anti Diabetik dengan Regulasi Kadar Gula Darah pada Pasien Perempuan Diabetes Mellitus. Amerta Nutr 2018.

36. Indah DP. Hubungan Pengetahuan Tentang Diet Diabetes Mellitus Dengan Kepatuhan Pelaksanaan Diet Pada Penderita Diabetes Mellitus. J Keperawatan Kebidanan 2011. 